
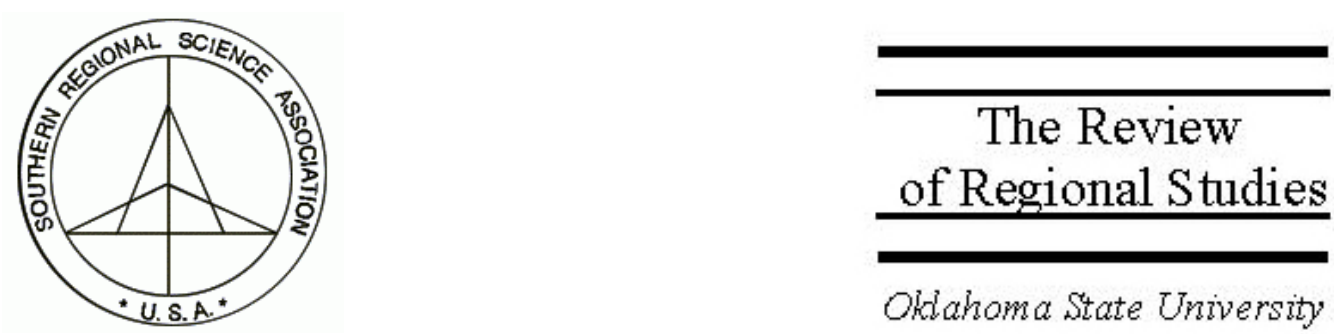

\title{
Does Economic Vulnerability Depend on Place of Residence? Asset Poverty across Metropolitan and Nonmetropolitan Areas
}

\author{
Monica Fisher \\ University of Missouri, Truman School of Public Policy and Rural Poverty Research \\ Center, Oregon State University, 213 Ballard Hall, Corvallis, OR 97331, \\ e-mail: monica.fisher@oregonstate.edu \\ Bruce A. Weber \\ Department of Agricultural and Resource Economics and Rural Poverty Research \\ Center, Oregon State University, 213 Ballard Hall, Corvallis, OR 97331, \\ e-mail: bruce.weber@oregonstate.edu
}

\begin{abstract}
This paper uses PSID data for 1989, 1994, and 1999 to examine why some U.S. households are asset poor, i.e., why households have insufficient resources to invest or to sustain household members at a basic level during times of economic disruption. The study contributes to an improved understanding of asset poverty's correlates by examining the influence of place of residence; the extant literature has focused on individual-level explanations. We estimate a random-effects logistic model of the probability that an individual is asset poor at a given point in time as a function of household (e.g., gender and race of the head, family structure) and place (region and metropolitan or nonmetropolitan county) variables. The central finding of the paper is that place of residence is an important determinant of asset poverty, above and beyond the influence of household characteristics. We find that living in a central metropolitan county and in a nonmetropolitan area is associated with a higher risk of being asset poor, all else being equal.

Keywords: Economic well-being; Asset accumulation; Poverty measurement; Rural; Urban

JEL classification: I32; R20

This research was supported by the Rural Poverty Research Center of the Rural Policy Research Institute, Columbia, Missouri. We thank Maureen Kilkenny, Dan Rickman, and two anonymous reviewers for valuable comments on an earlier version of the paper. They bear no responsibility for remaining shortcomings.
\end{abstract}




\section{INTRODUCTION}

Traditionally, poverty reduction policy in the United States has focused on income transfers to low-income families. Recently, however, programs that promote asset accumulation among the poor, such as Individual Development Accounts (IDAs), have been integrated into federal antipoverty efforts. The interest in asset building for poverty alleviation reflects growing dissatisfaction with means-tested welfare policy as well as changing views on what constitutes economic poverty. Increasingly, scholars argue that poverty is not only a lack of income or consumption, but a lack of assets as well (e.g., Haveman and Wolff 2000; Oliver and Shapiro1990; Sherraden 1991).

An emerging literature seeks to identify the asset poor - those households with insufficient resources to invest in their future or to sustain household members at a basic level during times of economic disruption. Research indicates that the incidence of asset poverty far exceeds that of income poverty. In 1998, for example, 10 percent of households were income poor while an estimated 26 to 40 percent of households were asset poor, depending on how wealth is defined (Haveman and Wolff 2000). Studies of asset poverty also show that wealth is more unequally distributed than income. Wolff (2001) reports that the top 20 percent of households earn 56 percent of the nation's income and own 83 percent of national wealth. These findings highlight the need for research that improves our understanding of why households are asset poor and which factors encourage or discourage household asset accumulation.

This study uses data from the Panel Study of Income Dynamics (PSID) to examine potential links between place of residence and asset poverty. We ask if there is a differential risk of being asset poor in nonmetropolitan (nonmetro) compared with metropolitan (metro) areas. ${ }^{1}$ Our study is motivated by evidence that income poverty is geographically concentrated in central cities of large metro areas and in rural places (Brown and Hirschl 1995; Cotter 2002; Danziger 2002) and by empirical evidence of more variable employment in rural versus urban localities (Brady, Sprague, and Gey 2002; Thompson and Hammond 2001). The implication may be that residents of certain places have a greater need for financial assets to help them withstand income shortfalls and make investments to provide for a better future.

The present paper complements existing research on asset poverty's correlates that has thus far focused on individual-level explanations. Key findings are that asset-poor households are more likely to be headed by an individual who is young, African American, female, unmarried, and less educated (Caner and Wolff 2002). People who reside in certain localities may also face particularly severe challenges to wealth accumulation, due to the differential distribution of economic opportunities and resources across space. By analyzing the influence of place on asset poverty, the present paper

\footnotetext{
$\overline{1}$ The terms "nonmetro" and "rural" are used interchangeably in this paper to refer to counties outside of metropolitan areas.
} 
provides information to assist policymakers in better targeting antipoverty programs to both the people and the locations in greatest need.

\section{ASSETS, ECONOMIC WELL-BEING, AND PLACE OF RESIDENCE}

A key argument in the current debate about poverty measurement in the U.S. is that income alone is an insufficient indicator of economic well being. ${ }^{2}$ Various alternative or supplementary measures have been proposed, including consumption- and wealth-based indicators (e.g., Slesnick 1993; Haveman and Wolff 2000). In this paper we view household assets as a welfare measure that is complementary to household income; together the two measures provide a more complete picture of economic well being.

The level of a household's income indicates its current ability to consume goods and services and support a certain living standard. Likewise, wealth - the total amount of a household's accumulated assets - can be used to purchase food and other necessities. Thus, both income and wealth provide an indication of the ability to meet current consumption needs. This information is important, but human welfare assessments should also tell us about a household's economic stability and its ability to invest and provide for a better future. Information on asset holdings is useful for such purpose.

Wealth provides a household with economic stability, because households with liquid assets are better able to endure income shortfalls. A household experiencing temporary low income due to job loss of a household member could be classified as income poor. In fact such a household may not experience economic hardship if liquid assets are available to smooth consumption over income fluctuations. Another key role of assets is in providing a foundation for risk taking that leads over time to resource accumulation (Sherraden 1991). For instance, household savings can be used to start up a business or invest in a child's education. Thus, while a lack of income means that people struggle to get by, a lack of assets can prevent them from getting ahead. Some assets provide important non-monetary benefits. Home ownership, for example, offers services beyond shelter, in the form of access to location-linked amenities such as better schools, community services, and safer neighborhoods (Shapiro and Wolff 2001). In sum, assets are important to human welfare in ways that go beyond current consumption.

Unfortunately, the accumulation of household assets may be impeded in struggling areas such as remote-rural areas or central cities. For example, the expansion of small businesses in some rural areas is hindered by aging infrastructure, lower skilled labor, and insufficient capital (McDaniel 2001). In addition, qualitative evidence suggests that limited funding sources and transportation-related constraints to participation in financial

\footnotetext{
${ }^{2}$ Other important criticisms of the official poverty measure include: (a) the official poverty thresholds are outdated, (b) the income measure does not include the value of in-kind benefits nor does it deduct payroll/income taxes as well as expenses required to hold a job and to obtain medical care, and (c) regional and metro/nonmetro cost-of-living differences are not taken into account (Citro and Michael 1995).
} 
education courses can impede the success of individual development account programs in rural areas (Curley and Grinstein-Weiss 2003). In many central cities, limited availability of bank financing and of venture capital serve as barriers to entrepreneurship (Dymski 1995). Furthermore, prospective homeowners in central cities are more likely to face problems of property insurance availability (Squires 2003). In sum, people who reside in certain localities may face particularly severe challenges to saving and asset accumulation, due to the differential distribution of economic opportunities and resources across space. Accordingly, in this study we examine both individual-level and place-based factors associated with asset poverty.

\section{ASSET POVERTY DEFINITIONS}

In this paper we seek to identify those households facing economic hardship and the factors associated with their economic position. A wide literature has examined the correlates of income poverty, both individual-level and place-based factors (e.g., Brown and Hirschl 1995; Cotter 2002; Iceland 1997). Less is known about why some households are asset poor, and there has been no past research on whether place of residence is associated with the likelihood of asset poverty. We here analyze the factors related to asset poverty, focusing on the role of place. Our results on asset poverty can complement research findings on income poverty to provide a more complete picture of economic hardship.

We follow others in the literature and define asset-poor households as those with insufficient wealth resources to meet their basic needs for some limited time period (Haveman and Wolff 2000). Using this definition requires that decisions be made concerning the definition of wealth resources and basic needs and the relevant time period. We set the time period to three months, as is common in the literature (e.g., Haveman and Wolff 2000; Oliver and Shapiro 1990). We consider three wealth concepts (see Table 1). The first, net worth, is the value of all assets less the value of all debts. Assets include equity in the household's home, real estate, vehicles, business, and farm; the value of shares of stock; the value of checking and saving accounts, money market funds, certificates of deposit, savings bonds, Treasury bills, and individual retirement accounts (IRAs); and the value of other forms of savings and assets such as investments in trusts of estates and life insurance policies. Debts include credit card charges, student loans, medical or legal bills, and loans from other sources such as relatives.

The second wealth concept used in the paper, net financial assets, is net worth minus home equity and vehicle equity. This measure accounts for the fact that home and vehicle equity are not straightforward sources of resources for investments such as financing a child's education or starting a business (Oliver and Shapiro 1990). Finally, we measure liquid assets as the sum of the value of shares of stock; the value of checking and saving accounts, money market funds, certificates of deposit, savings bonds, Treasury bills, and IRAs; and the value of other forms of savings and assets such as life insurance policies. 
Fisher and Weber: Does Economic Vulnerability Depend on Place of Residence?

TABLE 1

Definitions of Wealth Concepts: Net Worth, Net Financial Assets, and Liquid Assets ${ }^{\text {a }}$

\begin{tabular}{|c|c|c|c|}
\hline & Net Worth & Net Financial Assets & Liquid Assets \\
\hline Main home (net value) ${ }^{b}$ & + & & \\
\hline Other real estate (net value) & + & + & \\
\hline Farm and business (net value) & + & + & \\
\hline Vehicles (net value) & + & & \\
\hline Stocks $^{c}$ & + & + & + \\
\hline Checking and saving accounts ${ }^{d}$ & + & + & + \\
\hline Other savings ${ }^{e}$ & + & + & + \\
\hline Other debt ${ }^{\mathrm{f}}$ & - & - & \\
\hline \multicolumn{4}{|c|}{$\begin{array}{l}\text { a + indicates addition to wealth and - indicates subtraction from wealth. } \\
\text { b House value minus remaining mortgage principal. } \\
\text { c Value of shares of stocks in publicly held corporations, mutual funds, and investment trusts. } \\
\text { d Checking and saving accounts, money market funds, certificates of deposit, savings bonds, Treasury bills, } \\
\text { and individual retirement accounts. } \\
\text { e Other savings and assets, including bond funds, cash value of life insurance policies, special collections, } \\
\text { and rights in a trust or estate. }\end{array}$} \\
\hline
\end{tabular}

We compare the value of household wealth holdings with experimental poverty lines proposed by a National Academy of Science (NAS) panel, available for the years 1989 to 1999 (Short 2001, Table A-1). These thresholds represent the dollar amount that a reference family of two adults and two children requires to meet basic necessities of food, clothing, shelter, utilities, and a "little bit more" (e.g., household supplies and personal care). For each year, the threshold is adjusted for differing family size and structure using a three-parameter equivalence scale (Betson cited in Short 2001). ${ }^{3}$ The NAS poverty threshold should provide a more accurate means of gauging economic hardship compared with the official poverty line. Observers contend that the official poverty threshold is outdated, because its mechanics have remained essentially the same for 40 years, despite substantial changes in economic behavior among the U.S. population. These thresholds were developed in the 1960s by estimating the cost of a minimum adequate diet for households of different sizes multiplied by three to allow for other items (Citro and Michael 1995). To account for price changes, threshold values have been inflated each year using the Consumer Price Index. In sum, we define a household as asset poor if the value of its wealth resources is insufficient to sustain household members at the experimental poverty line for three months.

3 For single-parent families the formula is: $(A+0.8+0.5 *(C-1))^{0.7}$, where $A$ is number of adults and $C$ is number of children. For all other families, the formula $(A+0.5 * C)^{0.7}$ is used. Note that we define single-parent families as those families with children in which the household head did not have a wife, husband, or long-term cohabitator. 


\section{DATA AND EMPIRICAL MODEL}

The study uses PSID data to analyze asset poverty across rural and urban places. The PSID is a longitudinal survey that has followed a representative sample of 5,000 families and their descendents since 1968 (see Brown, Duncan, and Stafford 1996 and Hill 1992 for detailed descriptions of the PSID). The PSID family and individual files contain data on demographics, employment, earnings, and income. Data on household asset holdings are provided in the supplemental wealth modules conducted every five years from 19841999 and again in 2001 (see Hurst et al 1998 for a summary). ${ }^{4}$ PSID data on the Beale Code of county of residence permit classification of metro areas by population size and nonmetro areas according to population size as well as adjacency and nonadjacency to a metro area for the years 1985-1993, 1999, and 2001.

Two types of samples are compiled for the study's analyses. The paper's descriptive analyses use cross-sectional samples of all PSID responding households in 1989, 1994, and 1999. As stated earlier, these three years are the only ones for which both supplementary wealth data and NAS poverty thresholds are available. The study's multivariate analyses use a longitudinal sample consisting of all PSID individuals residing in interviewed households at the time of the 1989, 1994, and 1999 interviews. We track individuals rather than households over time because it is difficult to arrive at a satisfactory definition of a "longitudinal household" (see Duncan and Hill 1985 for a detailed discussion). For the PSID data, tracking households over time would require that we identify households that remained the "same" across the time period (e.g., the household head did not change), and only these households would be longitudinal ones. The resulting sample would be a highly selective one because households experience substantial composition change even over short time periods (Duncan and Hill 1985). ${ }^{5}$ While the study's analysis unit is the individual, for the regression analyses we attribute to each person the characteristics of his or her household because poverty is a household-level variable.

The empirical model used to examine whether there is a higher risk of poverty in rural versus urban areas is a random-effects logistic model. The model takes the form:

\footnotetext{
${ }^{4}$ Nonresponse rates for the wealth questions are exceptionally low in the PSID, less than 1 percent for different wealth components, likely due to the familiarity between respondents and interviewers that comes with a longitudinal survey. Trust developed over years of experience with the PSID should also have a favorable effect on the accuracy of information for these sensitive questions (Hurst et al. 1998).

${ }^{5}$ One drawback of using individuals as the analysis unit is that this introduces clustering in the data. For example, at a given point in time a household made up of three asset-poor individuals counts as three separate poverty observations. Unfortunately, this statistical issue cannot be dealt with by explicitly accounting for such clustering in the empirical model because to do so requires one to define longitudinal households. In practical terms, the PSID data do not have unique timevarying household identifiers, although such identifiers are available for individuals.
} 


$$
Y_{i r t}=\alpha_{0}+\alpha_{1} X_{i t}+\alpha_{2} Z_{r t}+v_{i r t}
$$

where subscripts $i, r$, and $t$ denote individuals, place, and time, respectively. Dependent variable $Y$ is the probability that an individual lives in a household that is asset poor. Explanatory variables are individual and household characteristics $X$ (including the number of children and adults in the household as well as the household head's age, race, gender, marital status, education, and current employment status) and contextual variables $Z$ (binary variables for region and metro/nonmetro residence). Term $v$ is an error term that, in the random-effects model, consists of three components:

$$
v_{i r t}=\gamma_{i}+\mu_{t}+\varepsilon_{i r t}
$$

where $\gamma$ represents omitted variables that vary across individuals but not over time, $\mu$ denotes omitted variables that vary over time but are constant across individuals, and $\varepsilon$ is the usual error term in statistical models.

The basis of our choice to use a random-effects model rather than a fixed-effects specification deserves mention. ${ }^{6}$ There are some important advantages of the randomeffects approach relative to a fixed-effects model. One, random effects is more efficient because it uses more information than does fixed effects. Two, unlike the fixed-effects model, time-invariant variables can be included in the random-effects model (Johnson 1995). Unfortunately, the random-effects model has an important drawback: it assumes the error term is uncorrelated with all explanatory variables (Hsiao 1986). For this reason some analysts contend that fixed effects is nearly always preferable in social science settings (Allison 1994). We cannot, however, employ a fixed-effects specification in our case. For fixed-effects logistic models, any group having all positive or all negative outcomes is dropped from the analysis. In our case, any individual who was either poor or not poor in all years is dropped, amounting to 80 percent of observations. The exclusion of these observations leaves us with a highly selective sample and, subsequently, biased coefficient estimates for the fixed-effects specification.

Table 2 provides descriptive statistics of explanatory variables in the econometric estimation. The regressors of primary interest here are a set of binary variables indicating residence in a central metro, other large metro, smaller metro, nonmetro adjacent, and nonmetro nonadjacent county. The sign and relative magnitude of the point estimates for these variables allows us to examine whether there is a differential risk of being asset

\footnotetext{
${ }^{6}$ Random-effects and fixed-effects models, which differ in their treatment of omitted variables, are commonly used to analyze panel data. In the fixed-effects model, individual-varying, timeinvariant (e.g., gender or "motivation") and time-varying, individual-invariant (e.g., interest rates) omitted variables are assumed to be constants and enter as binary variables in the regression equation. In random effects, omitted variables are viewed as random and the error term has three components: the usual error term, randomness due to individual, time-invariant omitted variables, and a random variable reflecting time, individual-invariant omitted variables (Hsiao 1986).
} 
poor in nonmetro compared with metro areas. It is important to mention that Beale code data are not available for 1994 in the PSID public-use data. For this reason we use the Beale code data for 1993 to represent 1994 values. This procedure introduces bias into the analysis if some households residing in urban (rural) places in 1993 had moved to a rural (urban) location by 1994. The magnitude of such bias may be small because the number of moves between rural and urban places over the course of a year should not be large. Table 3, which documents residential moves across rural and urban areas in the early 1990s, provides support for this contention.

\section{EMPIRICAL RESULTS}

\subsection{Descriptive Results}

We begin by examining rates of income and asset poverty over time (see Figure 1). Note that all of the descriptive statistics that follow use household weights allowing us to compute national estimates. Consider first the two income poverty measures. We see that using the NAS threshold rather than the official threshold has little impact on measured poverty. ${ }^{7}$ Comparing income and asset poverty, the large differences in measured poverty are striking. The net worth poverty rate is about twice the income poverty rate, while net financial asset and liquid asset poverty rates are both about four times the level of income poverty rates. The similarity in poverty rates for the net financial asset and liquid asset measures is explained by low ownership rates of illiquid assets other than primary residence as well as the inclusion of debt in net financial but not liquid assets.

Figure 1 shows more movement in income poverty than in asset poverty over the time period. This is as expected since wealth, unlike income, is accumulated over a lifetime and is rather stable over time, with large changes in wealth occurring only in rare circumstances such as inheritance or extreme income shocks (Oliver and Shapiro 1990). Income poverty increased slightly between 1989 and 1994 and then fell by a few percentage points from 1994 to 1999 . Such a pattern is expected given the recession of the early 1990s and economic expansion in the late 1990s. By contrast, asset poverty rates hardly changed between 1989 and 1994 and then increased one to three percentage points from 1994 to 1999 . It is possible that the asset poverty gap index would tell a different story than the asset poverty headcount, one that conforms better to trends in the wider economy. Caner and Wolff (2002), for example, also find that the percentage of households that were asset poor changed little between 1989 and 1994. Their calculation of the asset poverty gap index, however, shows that asset-poor households were on average 75 percent and 89 percent below the poverty line in 1989 and 1994, respectively.

\footnotetext{
${ }^{7}$ Income poverty rates reported in Figure 1 are lower than the official poverty rates calculated using Current Population Survey (CPS) data. Stevens (1994) states that the consistently lower poverty rates calculated with PSID data appear to be the result of more thorough income reporting in the PSID compared with the CPS. For this reason, analysts using PSID data often use a more generous cut-off point, say 125 percent of the Census Bureau's official poverty threshold, in their poverty calculations (e.g., Iceland 1997; Stevens 1994).
} 
Fisher and Weber: Does Economic Vulnerability Depend on Place of Residence?

TABLE 2

Descriptive Statistics of Explanatory Variables

\begin{tabular}{|c|c|c|}
\hline & Mean or Frequency & Standard Deviation \\
\hline \multicolumn{3}{|l|}{ Household-level characteristics } \\
\hline Age of household head (years) & 43.63 & 13.62 \\
\hline Head is female $(0=$ No; $1=$ Yes $)$ & 0.22 & ---- \\
\hline Head's race is African American $(0=\mathrm{No} ; 1=\mathrm{Yes})^{\mathrm{a}}$ & 0.33 & ---- \\
\hline Head is "married" $(0=\text { No; } 1=\mathrm{Yes})^{\mathrm{b}}$ & 0.72 & ---- \\
\hline \multicolumn{3}{|l|}{ Head's highest level of education } \\
\hline Less than high school degree $(0=\mathrm{No} ; 1=\mathrm{Yes})$ & 0.20 & ---- \\
\hline High school diploma $(0=$ No; $1=$ Yes $)$ & 0.31 & ---- \\
\hline College attendance, no degree $(0=$ No; $1=$ Yes $)$ & 0.22 & ---- \\
\hline Head has college degree $(0=$ No; $1=$ Yes $)$ & 0.27 & ---- \\
\hline \multicolumn{3}{|l|}{ Head's current employment status } \\
\hline Employed $(0=\text { No; } 1=\text { Yes })^{\mathrm{c}}$ & 0.79 & ---- \\
\hline Unemployed $(0=\mathrm{No} ; 1=\mathrm{Yes})^{\mathrm{c}}$ & 0.04 & ---- \\
\hline Retired $(0=$ No; $1=$ Yes $)$ & 0.10 & ---- \\
\hline Disabled $(0=\text { No; } 1=\text { Yes })^{c}$ & 0.03 & ---- \\
\hline Out of the labor force & 0.05 & --- \\
\hline Number of adults in household & 2.07 & 0.77 \\
\hline Number of children in household & 1.41 & 1.36 \\
\hline \multicolumn{3}{|l|}{ Place characteristics } \\
\hline \multicolumn{3}{|l|}{ County type } \\
\hline Central metro $(0=\text { No; } 1=\text { Yes })^{\mathrm{d}}$ & 0.25 & ---- \\
\hline Other large metro $(0=\text { No; } 1=\text { Yes })^{d}$ & 0.14 & ---- \\
\hline Smaller metro $(0=\mathrm{No} ; 1=\text { Yes })^{\mathrm{d}}$ & 0.32 & ---- \\
\hline Nonmetro adjacent $(0=\text { No; } 1=\text { Yes })^{d}$ & 0.12 & ---- \\
\hline Nonmetro nonadjacent $(0=\mathrm{No} ; 1=\text { Yes })^{\mathrm{d}}$ & 0.16 & ---- \\
\hline \multicolumn{3}{|l|}{ Region } \\
\hline Northeast $(0=$ No; $1=$ Yes $)$ & 0.16 & ---- \\
\hline Midwest $(0=$ No; $1=$ Yes $)$ & 0.28 & ---- \\
\hline South $(0=$ No; $1=$ Yes $)$ & 0.42 & ---- \\
\hline West $(0=$ No; $1=$ Yes $)$ & 0.15 & ---- \\
\hline \multicolumn{3}{|c|}{$\begin{array}{l}\text { a Only African Americans and whites are included in the analyses, because the number of Latino and Asian } \\
\text { respondents is very small. } \\
\mathrm{b} \text { Head is married or has a cohabitator with whom he/she has lived for at least one year. } \\
\text { c The employed are currently working, temporarily laid off, or on leave due to illness or pregnancy. The } \\
\text { unemployed are not working, but actively seeking work. Those out of the labor force are keeping house, } \\
\text { students, on workfare, in prison/jail, or "other". }\end{array}$} \\
\hline \multicolumn{3}{|c|}{$\begin{array}{l}\text { The corresponding Beale-Ross Rural-Urban Continuum codes are: central metro (code 0), other large metro } \\
\text { (code 1), smaller metro (codes } 2 \text { and 3), nonmetro adjacent (codes 4, 6, and 8), and nonmetro nonadjacent } \\
\text { (codes 5, 7, and 9). }\end{array}$} \\
\hline
\end{tabular}


TABLE 3

Household Moves across Rural and Urban Counties, 1989-1993

\begin{tabular}{lcccc}
\hline & $1989-1990$ & $1990-1991$ & $1991-1992$ & $1992-1993$ \\
\hline Remained in rural county (percent) & 23.08 & 19.76 & 19.73 & 18.61 \\
Remained in urban county (percent) & 75.24 & 78.97 & 78.53 & 77.92 \\
Rural to urban move (percent) & 0.81 & 0.55 & 0.79 & 1.96 \\
Urban to rural move (percent) & 0.86 & 0.72 & 0.95 & 1.50 \\
\hline
\end{tabular}

FIGURE 1

Income and Asset Poverty Rates, 1989 to 1999

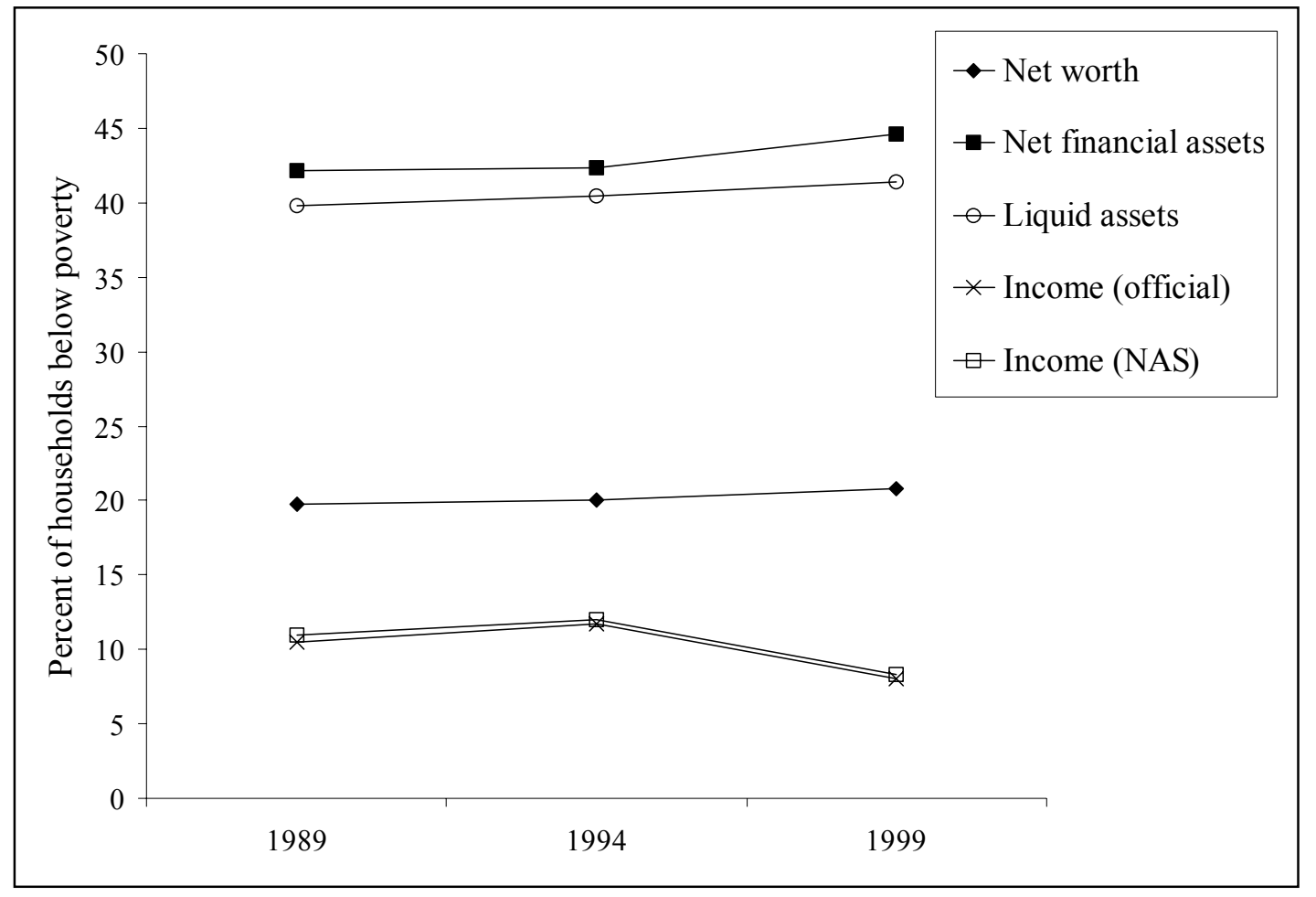

Source: Authors' calculations using PSID data

Data are weighted with family weights. Sample sizes are between 5,299 and 7,414 households. 
Figures 2 and 3 present levels of income and asset poverty across metro and nonmetro areas for 1999. The familiar story that poverty is higher in nonmetro than metro areas is evident from the figures if one considers metro and nonmetro aggregates. Our geographic classification uncovers important differences within rural and urban places and indicates that central cities and remote rural areas have the highest income poverty rates.

Figure 3 tells a rather different story than does Figure 2. Depending on how wealth is defined, one could conclude that asset poverty is higher in rural or urban places. Net worth poverty is highest in central metro counties and lowest in other large metro counties. Note that these geographic categories loosely correspond to central city and suburb, respectively. In the aggregate, the net worth poverty rate is 22 percent in urban areas and 19 percent in rural areas. This is largely a reflection of higher home ownership in rural versus urban areas. The incidence of net financial asset poverty is higher in central metro counties followed closely by nonmetro nonadjacent and nonmetro adjacent counties. When we turn to liquid asset poverty, we see that rural residents, particularly those not adjacent to a metro area, are more likely to be poor than their counterparts in urban areas. The observed differences in who is more likely to be asset poor depending on whether one defines wealth in net financial or liquid asset terms are explained as follows. First, on average, rural households hold relatively few liquid assets such as checking/saving accounts or stocks; rather most of their wealth is in illiquid assets such as personal residence, farm, or real estate. Second, our sample of rural households had lower average levels of debt than their urban counterparts. For example, in 1999, the weighted mean for household debt was $\$ 5,826$ and $\$ 4,817$ for metro and nonmetro households, respectively. We turn now to multivariate results to determine whether observed metro-nonmetro differences remain when we introduce controls for household characteristics and region of residence.

\subsection{Multivariate Results}

Table 4 presents random-effects logistic model results for asset poverty. Coefficients, standard errors, and marginal effects are reported in the table. ${ }^{8}$ We begin with discussion of the household characteristic variables. The results for these variables are similar to those obtained in other analyses of asset poverty correlates (e.g., Caner and Wolff 2002; Haveman and Wolff 2000). Nearly all of the point estimates for household characteristics are statistically significant at the 5 percent level. We find that individuals residing in households with an older head are less likely to be asset poor, all else being equal. The association between age and asset poverty is negative within reasonable bounds. (The turnover point, where the correlation between age and poverty becomes positive, is 175 years.) Living in a household with an African American head compared to one with a white head increases an individual's chances of living in poverty by as much as 40 percent. Findings also indicate that controlling for other key factors, people

\footnotetext{
${ }^{8}$ For binary variables, the marginal effects are interpreted as the percentage change in the probability of asset poverty resulting from a discrete change in the explanatory variable.
} 
are more likely to be poor if they live in a female-headed (versus male-headed) household and less likely to be asset poor if the household head is married.

Results in Table 4 provide evidence of positive returns to education. Individuals residing in households where the head did not complete high school (the reference category) are more likely to be asset poor compared with those in households where the head is more educated. Findings also indicate that individuals living in households with an employed head are far less likely to live in poverty compared with people in households where the head is disabled, unemployed, out of the labor force, or retired. Ideally we would include in the model a variable for number of earners in the household. Such a variable is not available in the PSID data, so we use number of adults to represent potential number of workers. The variable has an unexpected positive sign in the net financial asset and liquid asset equations. Since our model controls for marital status of the individual, the positive correlation between asset poverty and number of adults might in part reflect the presence of, and hence the need to support, indigent (e.g., nonworking, elderly) adults. Number of children is found to be positively correlated with the probability that an individual is part of a poor household.

\section{FIGURE 2}

Income Poverty Rates Across Metro and Nonmetro Areas, 1999

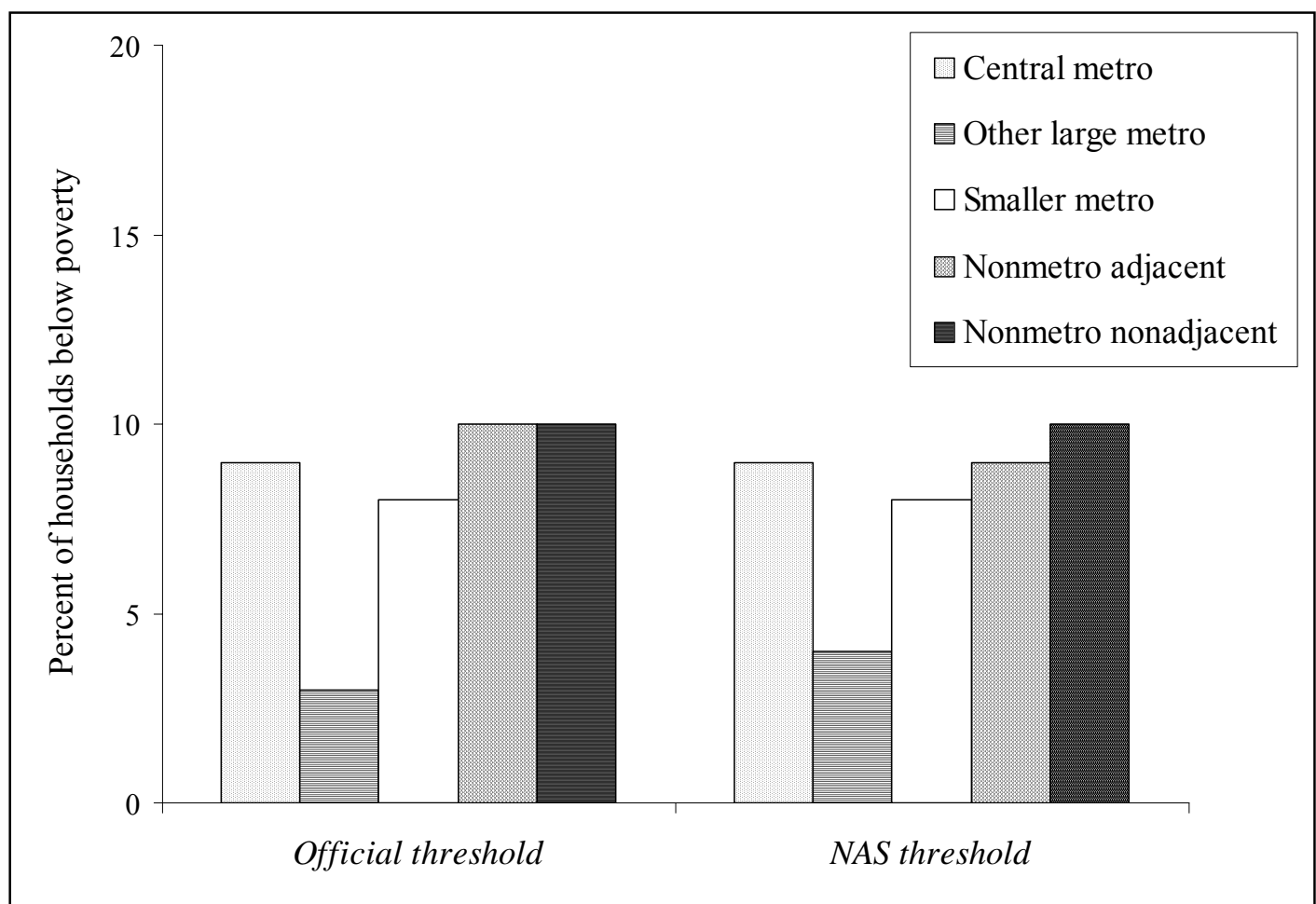

Source: Authors' calculations using PSID data

Data are weighted with family weights. Sample size is 5,299 households. 


\section{FIGURE 3}

Asset Poverty Rates Across Metro and Nonmetro Areas, 1999

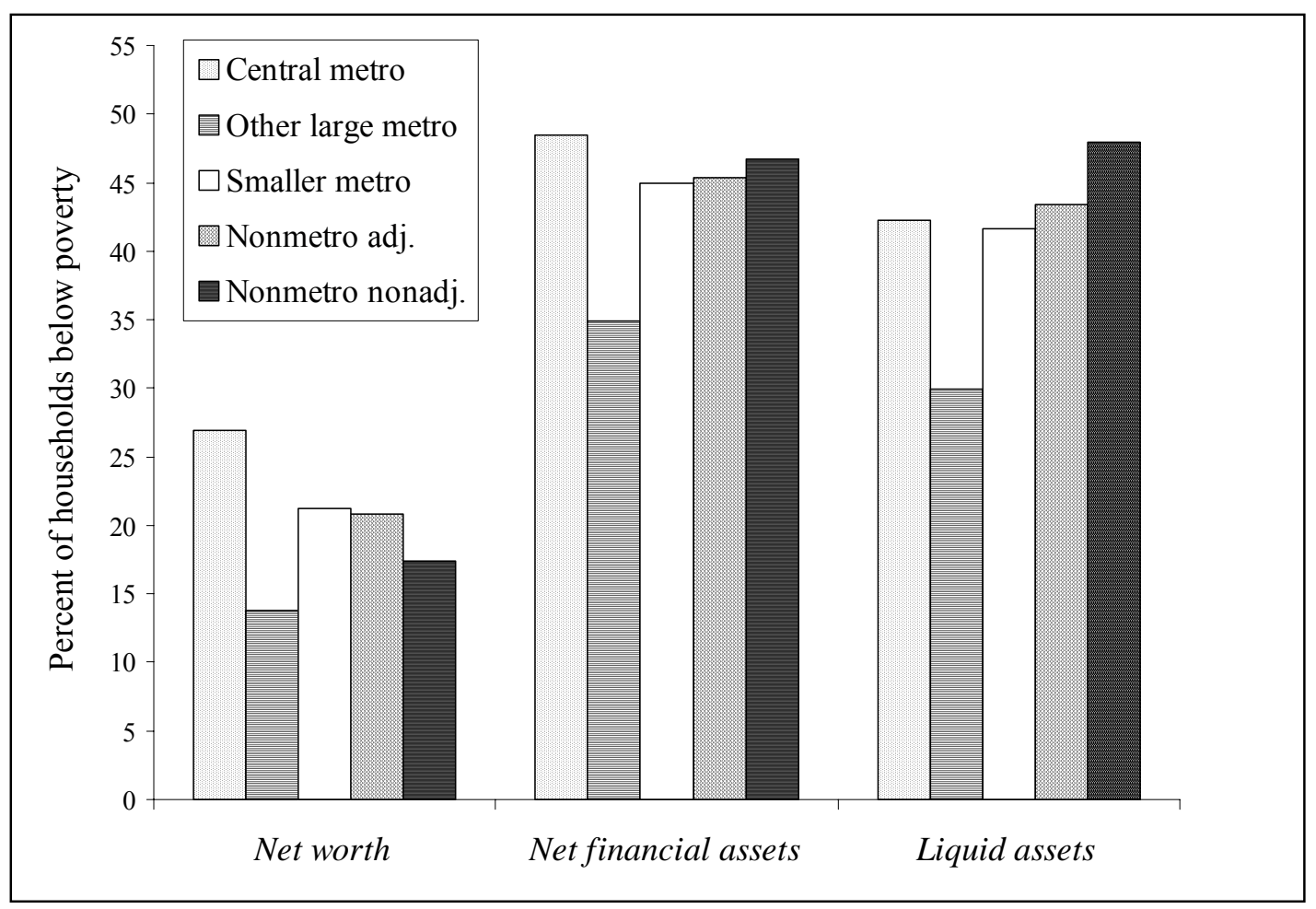

Source: Authors' calculations using PSID data

Data are weighted with family weights. Sample size is 5,866 households.

Our findings on how place of residence affects the probability of being asset poor are new. There has been no prior attempt to examine links between community context and asset poverty. Importantly, results in Table 4 show that place variables are strong predictors of asset poverty, above and beyond household characteristics. The bottom of Table 4 reports Wald statistics used to test the hypothesis of joint significance of the place variables. These variables are jointly significant at the 5 percent level, suggesting that their inclusion increases the explanatory power of the asset poverty models. Studies of income poverty commonly find a positive correlation between residence in the south and the likelihood of being poor. Our results are, for the most part, consistent with such a finding. Relative to their counterparts in the west, people living in the south are more likely to be poor in terms of their holdings of net financial and liquid assets. For net worth poverty, people living in the midwest region have a higher probability of being asset poor compared with inhabitants of the west, all else being equal.

We turn now to the central research question: Is there a differential risk of being asset poor in nonmetro compared with metro areas? The answer appears to depend on how one defines wealth. All else being equal, individuals living in central metro counties 
TABLE 4

Random-Effects Logistics Regression Results, Asset Poverty

\begin{tabular}{|c|c|c|c|c|c|c|c|c|c|}
\hline & \multicolumn{3}{|c|}{ Net Worth Poor } & \multicolumn{3}{|c|}{ Net Financial Asset Poor } & \multicolumn{3}{|c|}{ Liquid Asset Poor } \\
\hline & $\begin{array}{l}\text { Parameter } \\
\text { Estimate }\end{array}$ & $\begin{array}{c}\text { Stand. } \\
\text { Error }\end{array}$ & $\begin{array}{c}\text { Marginal } \\
\text { Effect }\end{array}$ & $\begin{array}{l}\text { Parameter } \\
\text { Estimate }\end{array}$ & $\begin{array}{c}\text { Stand. } \\
\text { Error }\end{array}$ & $\begin{array}{c}\text { Marginal } \\
\text { Effect }\end{array}$ & $\begin{array}{c}\text { Parameter } \\
\text { Estimate }\end{array}$ & $\begin{array}{c}\text { Stand. } \\
\text { Error }\end{array}$ & $\begin{array}{c}\text { Marginal } \\
\text { Effect }\end{array}$ \\
\hline Constant & $2.9211^{*}$ & 0.2778 & -- & $5.1076^{*}$ & 0.2748 & --- & $4.0194 *$ & 0.2711 & --- \\
\hline \multicolumn{10}{|c|}{ Household Characteristics } \\
\hline Head's age & $-0.1598 *$ & 0.0116 & -0.0113 & $-0.2057 *$ & 0.0111 & -0.0513 & $-0.1670 *$ & 0.0110 & -0.0410 \\
\hline Age squared & $0.0009 *$ & 0.0001 & 0.0001 & $0.0013^{*}$ & 0.0001 & 0.0003 & $0.0011 *$ & 0.0001 & 0.0003 \\
\hline Head's race black & $1.1415^{*}$ & 0.0737 & 0.0978 & $1.7766^{*}$ & 0.0730 & 0.4124 & $1.7364 *$ & 0.0725 & 0.4087 \\
\hline Head is female & $0.6865^{*}$ & 0.1078 & 0.0576 & $0.6444 *$ & 0.1090 & 0.1593 & $0.4941 *$ & 0.1094 & 0.1223 \\
\hline Head is "married" & $-0.8524^{*}$ & 0.1065 & -0.0717 & $-0.7560 *$ & 0.1037 & -0.1864 & $-0.8886^{*}$ & 0.1048 & -0.2183 \\
\hline \multicolumn{10}{|c|}{ Head's Education (< high school excluded) } \\
\hline High school & $-0.9316^{*}$ & 0.0741 & -0.0577 & $-1.0145^{*}$ & 0.0768 & -0.2441 & $-1.1118^{*}$ & 0.0764 & -0.2565 \\
\hline Some college & $-1.0598 *$ & 0.0828 & -0.0600 & $-1.4769 *$ & 0.0835 & -0.3359 & $-1.7305^{*}$ & 0.0832 & -0.3625 \\
\hline College degree & $-1.6149 *$ & 0.0919 & -0.0887 & $-2.2731 *$ & 0.0860 & -0.4813 & $-2.8362 *$ & 0.0883 & -0.5323 \\
\hline \multicolumn{10}{|c|}{ Head's employment (employed excluded) } \\
\hline Unemployed & $1.1922 *$ & 0.1062 & 0.1337 & $0.8391 *$ & 0.1313 & 0.2019 & $1.1161 *$ & 0.1339 & 0.2684 \\
\hline Retired & $0.3085^{*}$ & 0.1431 & 0.0243 & 0.2034 & 0.1114 & 0.0508 & $0.2403 *$ & 0.1121 & 0.0595 \\
\hline Disabled & $1.3369 *$ & 0.1284 & 0.1596 & $1.7740 *$ & 0.1574 & 0.3693 & $1.7003 *$ & 0.1588 & 0.3782 \\
\hline Out labor force & $1.1100 *$ & 0.1086 & 0.1200 & $0.7133 *$ & 0.1271 & 0.1738 & $0.8579 *$ & 0.1270 & 0.2106 \\
\hline Number adults & -0.0433 & 0.0373 & -0.0031 & $0.4025 *$ & 0.0352 & 0.1005 & $0.3916^{*}$ & 0.0356 & 0.0961 \\
\hline Number children & $0.2038^{*}$ & 0.0204 & 0.0144 & $0.2333 *$ & 0.0203 & 0.0583 & $0.3214^{*}$ & 0.0206 & 0.0789 \\
\hline \multicolumn{10}{|c|}{ Place Variables } \\
\hline \multicolumn{10}{|c|}{ County type ("other large" metro excluded) } \\
\hline Central metro & $0.5336^{*}$ & 0.0967 & 0.0425 & $0.5629 *$ & 0.0850 & 0.1396 & $0.4400 *$ & 0.0870 & 0.1088 \\
\hline Smaller metro & 0.1686 & 0.0946 & 0.0123 & $0.5853 *$ & 0.0809 & 0.1452 & $0.6386^{*}$ & 0.0830 & 0.1573 \\
\hline Nonmetro adj. & $0.2758 *$ & 0.1127 & 0.0213 & $0.7387^{*}$ & 0.0969 & 0.1807 & $1.0331 *$ & 0.0985 & 0.2519 \\
\hline Nonmetro nonadj. & 0.0631 & 0.1091 & 0.0046 & $0.7265^{*}$ & 0.0959 & 0.1783 & $1.1739 *$ & 0.0974 & 0.2843 \\
\hline
\end{tabular}




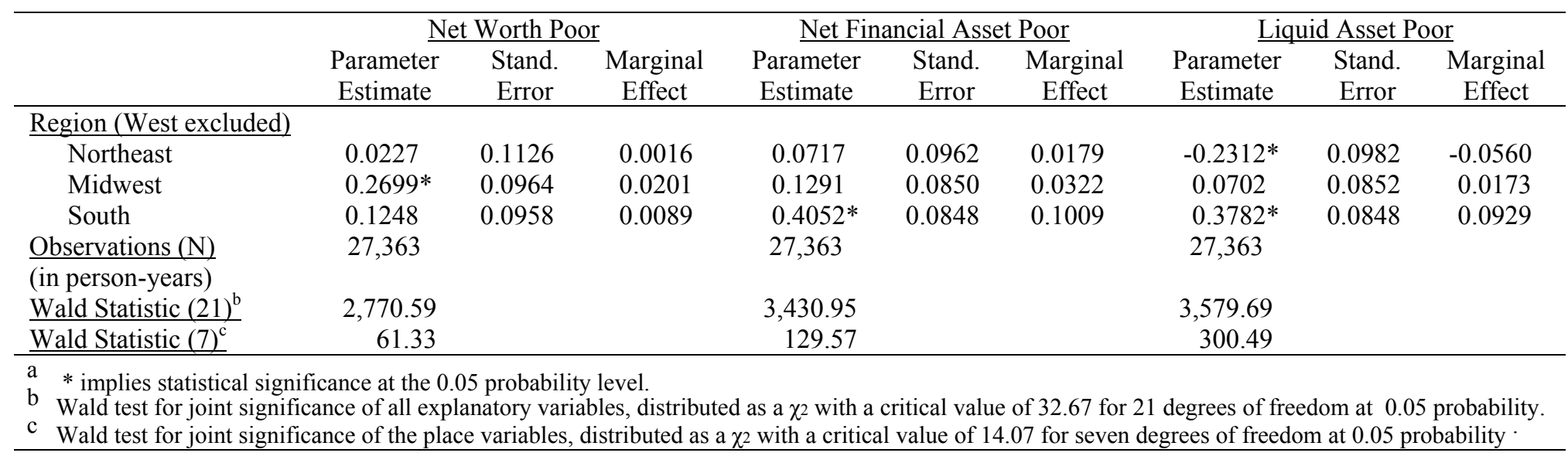


and in nonmetro adjacent counties are more likely to be net worth poor compared with residents of other large metro counties. The largest marginal effect among the county variables is for central metro counties where people are 55 percent more likely to be net worth poor compared with residents of other large metro counties. ${ }^{9}$ Estimation of the net worth poverty model with central metro county as the excluded county type finds that each of the other county-type variables has a negative coefficient that is statistically significant at the 95 percent confidence level (results available upon request). This suggests that central metro county residents are more likely to be net worth poor than are inhabitants of other county types.

For net financial asset poverty, parameter estimates for county type variables are positive and statistically significant. Thus, individuals who live in other large metro counties are less likely to be asset poor than are those who live in other county types. The largest marginal effect among these variables is for nonmetro adjacent counties where people are 38 percent more likely to be poor in net financial assets than residents of other large metro counties. We re-estimated the net financial asset poverty model with nonmetro adjacent county as the reference category and found that each of the urban county (central metro, other large metro, and smaller metro) variables has a negative and statistically significant coefficient. Thus, it appears that nonmetro county residents are more likely than metro county inhabitants to be net financial asset poor.

Results for liquid asset poverty (see Table 4) show that place of residence matters to asset poverty: each of the county type variables is positive and statistically significant. We find that individuals living in nonmetro nonadjacent counties have a 65 percent higher probability of being liquid asset poor compared with people residing in other large metro areas. Again, re-estimation of the model using a different county type reference category helps identify the most disadvantaged locations. When nonmetro nonadjacent county is the excluded county type, each of the urban county variables has a parameter estimate that is of negative sign and statistically significant. This indicates that, ceteris paribus, people living in nonmetro nonadjacent counties are more likely to be liquid asset poor than are metro county residents.

\section{CONCLUSION AND RESEARCH IMPLICATIONS}

We have examined the relationship between place of residence and asset poverty using PSID data. The main contribution of the study is our explicit incorporation of place variables in empirical analysis of why some people in the United States have insufficient wealth holdings to support needed consumption for three months. Previous studies of asset poverty correlates have focused on individual-level explanations (e.g., Caner and Wolff 2002; Haveman and Wolff 2000). Our empirical models include, in addition to a standard set of household-level variables, regional dummy variables and five rural-urban

\footnotetext{
${ }^{9}$ Marginal effects in the Logit model indicate percentage point rather than percent change. To arrive at this percentage figure, we divided the marginal effect by the predicted probability of being net worth poor $(0.0767)$.
} 
continuum binaries. This allows us to examine whether there is a differential risk of being asset poor in nonmetro compared with metro areas.

The central finding of the paper is that place of residence is an important determinant of asset poverty, above and beyond the influence of household characteristics. Where are people most likely to be asset poor? Our results suggest that living in a central metro county is associated with a higher risk of being net worth poor, all else being equal. Findings also indicate that there is a higher risk of being net financial asset and liquid asset poor for residents of nonmetro compared with metro areas.

Taken together, the study findings appear to indicate that residents of central metro and nonmetro counties are both disadvantaged, but in different ways. Residents of central metro counties are less able to accumulate the two key real assets that Americans aspire to own, namely a house and a vehicle. ${ }^{10}$ As a result, people in central metro counties are less able to achieve the benefits that can come with home ownership such as access to important location-based amenities (e.g., safer neighborhoods, better schools). In addition, because entry-level jobs in metro areas are increasingly located in distant suburbs (Allard 2001), lower vehicle ownership among central metro county residents may be a barrier to accessing entry-level jobs. Our findings show that nonmetro county residents are more likely to be net financial asset and liquid asset poor compared with people living in metro areas. Thus people in nonmetro areas may find it more difficult to cope with income shortfalls and make investments for a better future.

Our study underscores the importance of including place-level variables in future analyses of asset poverty correlates, but it also introduces new questions. Why are residents of central metro and nonmetro counties more likely to be asset poor? Are the relatively low home-ownership rates in central metro counties largely a reflection of higher house prices relative to household income in cities compared with other areas? Is the higher risk of liquid asset poverty in nonmetro nonadjacent areas related to poor access to financial institutions and/or a function of the seasonality of employment that causes people to draw down savings? There is a need for further study of what variables omitted in our analysis might help us better understand the asset accumulation barriers in central metro counties and nonmetro areas. Future empirical work should therefore control for key community characteristics such as labor market conditions, neighborhood poverty, the mean and variance of housing costs, and access to financial institutions. An improved understanding of the specific place-based factors associated with asset poverty will enable better targeting of asset-building programs to the places of greatest need.

\footnotetext{
${ }^{10}$ For illustration, the 1999 PSID data show that households living in central metro counties had lower home-ownership rates (weighted mean is 54 percent) than did households in other large metro (66 percent), smaller metro (62 percent), nonmetro adjacent (69 percent), and nonmetro nonadjacent (70 percent) counties.
} 
The Review of Regional Studies, Vol. 34, No. 2, 2004, pp. 137-155

\section{REFERENCES}

Allard, S.W., 2001. Place, Race and Work: The Dynamics of Welfare Reform in Metropolitan Detroit. The Brookings Institution Survey Series, Center on Urban and Metropolitan Policy: Washington, D.C.

Allison, P.D., 1994. "Using Panel Data to Estimate the Effects of Events," Sociological Methods and Research 23 (2), 174-199.

Brady, H., M.H. Sprague, and F.C. Gey, 2002. "Seasonal Employment Dynamics and Welfare Use in Agricultural and Rural California Counties," in B.A. Weber, G.J. Duncan, and L.A. Whitener (eds.), Rural Dimensions of Welfare Reform. W.E. Upjohn Institute for Employment Research: Kalamazoo, MI.

Brown, D.L. and T.A. Hirschl, 1995. "Household Poverty in Rural and MetropolitanCore Areas of the United States," Rural Sociology 60 (1), 44-66.

Brown, C., G.J. Duncan, and F.P. Stafford, 1996. "Data Watch: The Panel Study of Income Dynamics," The Journal of Economic Perspectives 10 (2), 155-168.

Caner A. and E. Wolff, 2002. "Asset Poverty in the United States, 1984-1999: Evidence from the Panel Study of Income Dynamics," The Levy Economics Institute Working Paper No. 356: New York.

Citro, C. and R. Michael, 1995. Measuring Poverty: A New Approach. National Academy Press: Washington, D.C.

Cotter, D.A, 2002. "Poor People in Poor Places: Local Opportunity Structures and Household Poverty," Rural Sociology 67 (4), 534-555.

Curley, J. and M. Grinstein-Weiss, 2003. "A Comparative Analysis of Rural and Urban Saving Performance in Individual Development Accounts," Washington University Center for Social Development Working Paper No. 03-08: St. Louis.

Danziger, S., 2002. "Approaching the Limit: Early National Lessons from Welfare Reform," in B.A. Weber, G.J. Duncan, and L.A. Whitener (eds.), Rural Dimensions of Welfare Reform. W.E. Upjohn Institute for Employment Research: Kalamazoo, MI.

Duncan, G.J. and M.S. Hill, 1985. "Conceptions of Longitudinal Households: Fertile or Futile?" Journal of Economic and Social Measurement 13, 361-375.

Dymski, G.A., 1995. "Business Strategy and Access to Capital in Inner-City Revitalization," Review of Black Political Economy 24 (2/3), 51-65.

Gould, W., 1999. "What is the Between Estimator?" Available at: http://www.stata.com/ support/faqs/stat/xt.html, March.

Haveman, R. and E. Wolff, 2000. "Who are the Asset Poor? Levels, Trends and Composition, 1983-1998," Washington University Center for Social Development Working Paper 00-12: St. Louis.

Hill, M.S., 1992. The Panel Study of Income Dynamics: A User's Guide. Sage Publications: Newbury Park, CA.

Hsiao, C., 1986. "Analysis of Panel Data," Econometric Society Monographs No. 11. Cambridge University Press: Cambridge, United Kingdom.

Hurst, E., M.C. Luoh, F.P. Stafford, and W.G. Gale, 1998. "The Wealth Dynamics of American Families, 1984-94," Brookings Papers on Economic Activity 1, 267-337. 
Iceland, J., 1997. "Urban Labor Markets and Transitions Out of Poverty," Demography 34 (3), 429-441.

Johnson, D.R., 1995. "Alternative Methods for the Quantitative Analysis of Panel Data in Family Research: Pooled Time-Series Models," Journal of Marriage and the Family 57 (11), 1065-1077.

McDaniel, K., 2001. "Small Business in Rural America." Federal Reserve Bank of Kansas City, Center for the Study of Rural America: Kansas City, MO.

Oliver, M.L. and T.M. Shapiro, 1990. "Wealth of a Nation: A Reassessment of Asset Inequality in America Shows at Least One Third of Households are Asset-Poor," American Journal of Economics and Sociology 49 (2), 129-151.

Shapiro, T.M. and E.N. Wolff, 2001. Assets for the Poor: The Benefits of Spreading Asset Ownership. Russell Sage Foundation: New York.

Sherraden, M., 1991. Assets and the Poor. M.E. Sharpe, Inc.: Armonk, NY.

Short, K., 2001. "Experimental Poverty Measures: 1999." U.S. Census Bureau Current Population Reports P60-216: Washington, D.C.

Slesnick, D.T., 1993. "Gaining Ground: Poverty in the Postwar United States," Journal of Political Economy 101(1), 1-38.

Squires, G.D., 2003. "Racial Profiling, Insurance Style: Insurance Redlining and the Uneven Development of Metropolitan Areas," Journal of Urban Affairs 25 (4), 391410.

Stevens, A.H., 1994 "The Dynamics of Poverty Spells: Updating Bane and Ellwood," AEA Papers and Proceedings 84 (2), 34-37.

Thompson, E. and G.W. Hammond, 2001. "Employment Risk in Nonmetropolitan Counties in the Southern United States," Tennessee Valley Authority Rural Studies Program, Contractor Paper No. 01-05: Knoxville, TN.

Wolff, E., 2001. "Recent Trends in Wealth Ownership, 1983-1998," in T. Shapiro and E. Wolff (eds.), Assets for the Poor. Russell Sage Foundation: New York. 